Persp. Teol. 38 (2006) 187-210

\title{
A CAMINHO DA V CONFERÊNCIA DE APARECIDA
}

João Batista Libanio, SJ

RESUMO: A Conferência de Aparecida vem na seqüência de quatro anteriores, sendo que as de Medellín, Puebla e Santo Domingo trouxeram contribuições pastorais ainda válidas para o dia de hoje. Antes de pensar questões novas, importa captar das três Assembléias e do Concílio Vaticano II as opções inegociáveis que devem ser reforçadas por Aparecida: Primado da Palavra de Deus, eclesiologia do Povo de Deus e suas implicações, opção pelos pobres e sua libertação, inculturação, protagonismo dos leigos, entre outras. Cabe avançar, assumindo os desafios do momento: animação carismática das estruturas internas da Igreja, evangelizar a nova sociedade globalizada e do conhecimento, evangelização inculturada, pastoral dos migrantes, desafio da midiática.

PAlAVRAS-CHAVE: Concílio Vaticano II, Medellín, Puebla, Santo Domingo, Igreja, Opções pastorais.

AвSTRACT: The "Aparecida" Conference comes in the sequence of four earlier ones, being such that the conferences of Medellín, Puebla and Santo Domingo brought forth pastoral contributions that are until this day still valid. Before thinking of new questions, it is important to captivate from the three Assemblies and the Second Vatican Council the non-negotiable options that must be reinforced for the Aparecida Conference: the Primacy of the Word of God; the ecclesiology of the People of God and its implications; the option for the poor people and their freedom; Inculturation; the protagonism of the lay people, among others. It is fitting to advance, assuming the challenges of the moment: the charismatic animation of the 
Church's internal structures, the evangelization of the new, globalized and knowledgeable society, cultural evangelization, the pastoral ministry for migrants and the challenge of mass media.

KEY-WORDS: Second Vatican Council; Medellín; Puebla; Santo Domingo; Church; Pastoral Options.

A conferência de Aparecida situa-se numa trajetória que vai desde o nascimento do CELAM até os nossos dias, passando pelo Concílio Vaticano II, Medellín, Puebla e Santo Domingo. O Concílio Vaticano II e Medellín marcaram etapas de abertura, enquanto as Conferências seguintes foram introduzindo adversativas nas suas opções fundamentais e inflexões de direção.

Alguns aspectos gerais caracterizam o momento atual no referente às opções básicas do Vaticano II e de Medellín. Nas décadas anteriores, elas se fizeram de maneira simples e radical. Hoje a situação se complexificou e se tornou plural de tal forma que se faz necessário voltar sobre elas a fim de reajustá-las ao momento sociocultural.

Deslocou-se a preocupação com as estruturas econômicas e políticas injustas para uma evangelização da cultura e para uma atenção ao gênero, à etnia e ao fenômeno religioso, especialmente do (neo)pentecostalismo. Saiu de foco a transformação da realidade sociopolítica e econômica por causa da percepção da inevitabilidade do sistema do neoliberalismo e do peso gigantesco de suas estruturas. Falar em mudança nesse campo soa pura ingenuidade e idealismo romântico.

Concomitantemente dentro da Igreja se processou uma virada para certa interiorização e clericalização em detrimento da opção pelos pobres e do compromisso social. Configurou-se para alguns críticos nítido neoconservadorismo ${ }^{1}$.

À distância de 40 anos do término do Concílio Vaticano II e quase o mesmo de Medellín, percebe-se que opções fundamentais de tais eventos não se implantaram ou se perderam nas últimas décadas. A análise do Do-

${ }^{1}$ J.I. GONZÁLEZ FAUS, "El meollo de la involución eclesial”, Razón y Fe 220 (1989/nn. 1089/90) 67-84; ID., "O neoconservadorismo. Um fenômeno social e religioso", Concilium (1981/n. 161); F. CARTAXO ROLIM, "Neoconservadorismo eclesiástico e uma estratégia política", REB 49 (1989) 259-281; J. COMBLIN, "O ressurgimento do tradicionalismo na teologia latino-americana", REB 50 (1990) 44-73; in P. BLANQUART, "Le pape en voyage: la géopolitique de Jean-Paul II", in P. LADRIÈRE / R. LUNEAU (orgs.), Le retour des certitudes. Événements et orthodoxie depuis Vatican II, Paris: Le Centurion, 1987, pp. 161-178; J.B. LIBANIO, La vuelta a la gran disciplina, B. Aires: Paulinas, 1986. 
cumento de Participação em vista da V Conferência em Aparecida, elaborada por A. Brighenti, confirma tal constatação. Ele assinala série de elementos criticáveis do documento. O ser humano aparece sem rosto, como se fosse uma categoria, uma essência. Na cristologia, apresenta-se um Cristo sem Jesus. Na eclesiologia, o Reino de Deus se eclipsa e a Igreja se isola do mundo. A preferência pelo termo missão em vez de evangelização reflete um contexto eclesiocêntrico de cristandade. A visão de mundo desloca-lhe a função de inspirador e desafiador da evangelização para palco de uma salvação meta-histórica. A preocupação missionária se concentra no fato do êxodo dos católicos em vez de questionar a qualidade da presença da Igreja na sociedade. Concluindo, o Documento de participação insere-se no gradativo distanciamento da legítima e original tradição latino-americana inaugurada em Medellín e, em última análise, das intuições e eixos teológicos centrais do Concílio Vaticano $\mathrm{II}^{2}$. Crítica contundente.

Levando em consideração as breves observações do contexto sócio-eclesial do Concílio Vaticano II até o Documento de Participação, cabe a tomada de dupla posição em vista da Assembléia de Aparecida:

1. Estabelecer com clareza as opções básicas e consideradas inegociáveis, imprescindíveis do Concílio Vaticano II e de Medellín, completadas com alguns ganhos de Puebla e Santo Domingo, para resistir e eventualmente reconstituir as que foram abandonadas.

2. Avançar para temas e decisões novas.

\section{Resistir e reconstituir as opções básicas}

\section{Introdução}

Um primeiro passo consiste em resistir na defesa das opções básicas do Vaticano II, Medellín, Puebla e Santo Domingo que devem ser mantidas e reconstruí-las no caso de que tenham sido desmontadas.

O fato da perda ou a não implantação das opções do Vaticano II e de Medellín decorre, com mediana clareza, da análise de conjuntura da Igreja que vem sendo feita por teólogos dos vários continentes ${ }^{3}$. A evolução eclesi-

\footnotetext{
${ }^{2}$ A. BRIGHENTI, V Conferência do Episcopado da América Latina. Este texto foi apresentado no Seminário comemorativo dos 40 anos do Concílio Vaticano II, organizado pelo Instituto Nacional de Pastoral da Conferência Nacional dos Bispos do Brasil em Itaici de 08 a 10 de fevereiro de 2006, em vias de publicação. Acessível em < www.adital.com.br $>$, 03.03.2006.

${ }^{3}$ Ver a citação anterior. Acrescente-se a obra: J.R. QUINN, Reforma do papado: indispensável para a unidade cristã, Aparecida: Santuário, 2002.
} 
ástica na América Latina nas últimas décadas tem confirmado tal avaliação. Basta analisar o desenrolar das sucessivas Conferências do Episcopado da América Latina cada vez menos sintonizadas com as opções anteriores. $\mathrm{O}$ aspecto consensual de tal percepção dispensa-nos maiores análises. Vale a pena tomar consciência, também de maneira bem sumária, de alguns fatores que influenciaram esse deslocamento.

No campo econômico, assistimos ao reinado solitário e despótico do neoliberalismo com as terríveis conseqüências que todos conhecemos. Implantaram-se democracias, em lugar dos regimes ditatoriais militares, mas que se puseram a serviço do neoliberalismo com pouca mudança para as camadas populares.

No campo cultural, desenvolveram-se tendências antitéticas. De um lado, continuou vertiginosamente o avanço da modernidade no mundo ocidental ou por ele diretamente influenciado. Tal fato se visibilizou especialmente no referente à tecnologia, especialmente à biotecnologia e à informática. A secularização diminuiu a relevância social da religião na esfera política. Doutro lado, instaurou-se aguda crítica à razão iluminista na expressão instrumental por causa dos hediondos crimes que cometeu máxime nas duas Grandes Guerras Mundiais. Fragmentou-se o saber de tal forma que se perdeu a visão de globalidade, tão ambicionada pela modernidade, na esteira de Hegel e Marx. E, por fim, explodiu surto religioso que relativizou o significado da secularização.

As repercussões não se fizeram esperar nas instâncias eclesiásticas. Maciço êxodo de católicos para denominações evangélicas fez os pastores voltarem a atenção para a conservação do próprio rebanho. No horizonte cultural soaram duas palavrinhas carregadas de explosivos que atemorizaram os arraiais eclesiásticos: relativismo e subjetivismo. Por todos os lados, as pessoas e os corpos sociais reivindicaram a própria verdade e autonomia, sabendo que ela se situava em universo plural e relativo. Ninguém já postulava a exclusividade da verdade. A Igreja não estava acostumada a viver em espaço de tal pluralismo e diversidade de verdade e valores. E via no seu seio aumentarem-se as livres experiências nos campos da liturgia, da disciplina, da vida religiosa, da educação, da pastoral, da expressão teológica, ameaçando a tranqüilidade serena da uniformidade.

As respostas se buscavam no nível da experiência religiosa. Surgiu o desafio estonteante da midiática. Em tudo isso, o magistério preocupava-se com a reta doutrina e com o enquadramento do clero e dos fiéis.

O sistema teológico sofreu o mesmo impacto da especialização que as ciências. Fragmentou-se em infinitas disciplinas e em correntes plurais. $\mathrm{O}$ surto espiritualista e carismático dos novos movimentos religiosos desinteressou-se das reflexões teológicas, lançando suspeita e descrédito sobre o mister de teólogo. E as instâncias romanas aumentaram a vigilância e controle sobre a teologia moderna européia e sobre a teologia da libertação com 
condenações de teólogos, emanaram orientações restritivas à vocação do teólogo ${ }^{4}$. E para tristeza geral, sofre-se até o momento a carência de teólogos de sínteses e visões amplas à Rahner. As últimas luzes fulgurantes, que iluminaram o Concílio Vaticano II, estão a apagar-se.

\section{Opções básicas do Vaticano II}

40 anos depois do término do Concílio Vaticano II, resgatemos-lhe as opções fundamentais que julgamos ainda balizas necessárias para a V Conferência de Aparecida. Em 1963, no início da 2a Sessão do Concílio, Paulo VI formulara a questão aos Padres do Vaticano II: "Igreja, que dizes de ti mesma?" E então, o que o Concílio respondeu, que nos norteia até hoje a compreensão da Igreja? Aqui não aprofundaremos nenhuma das respostas, mas as exporemos à guisa de listagem ${ }^{5}$.

\section{a. Primado absoluto da Palavra de Deus}

Na prática significou dois movimentos maravilhosos. Valorizou-se a Palavra nas liturgias, nas celebrações e em todas as atividades religiosas. Ela ocupou o devido lugar na produção teológica, na formação do clero e na vida dos fiéis. Multiplicaram-se as obras de exegese e sobre temas bíblicos, que ofereceram subsídios para o simples fiel alimentar-se espiritualmente da Escritura.

\section{b. Afirmação da base laical da Igreja: Igreja Povo de Deus}

Aconteceu revolução copernicana na concepção da Igreja. Em vez de partir da hierarquia para defini-la, afirmou-se o fato fundamental: todos somos iguais pelos sacramentos da Iniciação e na participação na Eucaristia. A Igreja se definiu como Povo de Deus. O leigo adquiriu nela o seu verdadeiro lugar, com amplo espaço de iniciativa, liberdade, autonomia, participação, gestação de espiritualidades próprias.

Em termos de América Latina, surgiram as primeiras comunidades eclesiais de base em íntima conexão com a experiência de novos ministérios leigos. Mais tarde, nas ondas de Medellín, as CEBs desenvolveram-se e Paulo VI aprofundou a compreensão dos ministérios não ordenados ${ }^{6}$.

\section{c. Afirmação colegial da Igreja}

Em íntima articulação com a base laical, o Vaticano II instilou um espírito colegial, superando o autoritarismo presente nos três centros: Roma, diocese,

${ }^{4}$ CONGREGAÇÃO PARA A DOUTRINA DA FÉ, Instrução sobre a vocação eclesial do teólogo, São Paulo: Paulinas, 1990.

${ }^{5}$ Para um aprofundamento remeto o leitor a meu livro: Concílio Vaticano II. Em busca de uma primeira compreensão, São Paulo: Loyola, 2005.

${ }^{6}$ Paulo VI, Evangelii nuntiandi (1974). 
paróquia. A colegialidade transformou-se em ar novo que se respirou no âmbito de toda a Igreja, valorizando a Igreja local, as comunidades. Criou-se uma consciência de sinodalidade e de comunhão, incrementando as Conferências episcopais, os Conselhos diocesanos, paroquiais e comunitários.

\section{d. Espírito ecumênico}

Desde a convocação atravessou todo o desenrolar do Concílio a aspiração ecumênica. Manifestou-se como verdadeira episteme, novo modo de pensar a Palavra de Deus e as práticas eclesiais. Influenciou o agir pastoral interno da Igreja em direção à comunhão ecumênica na oração, na produção teológica, na proximidade com os irmãos evangélicos na vida. No horizonte estava já a intercomunhão eucarística até hoje não realizada pela Igreja católica, enquanto outras Igrejas cristãs já a praticam ${ }^{7}$. Em ações pastorais, as Igrejas cristãs se uniram em comum preocupação social promocional e libertadora.

\section{e. Ampliação para o diálogo inter-religioso}

O Concílio abriu-se às grandes tradições religiosas do mundo. E no Continente latino-americano o diálogo religioso se defrontou com religiões indígenas e afroamericanas.

\section{f. Diálogo com o não crente: desde a liberdade religiosa}

A Constituição Pastoral Gaudium et spes lançou as bases para a construção do humanismo (cristão) baseado nos Direitos Humanos. Incentivou cristãos na luta pela justiça social em diálogo com irmãos não crentes dentro das entidades seculares. E a Igreja, enquanto Instituição, entendeu-se parceira de semelhante empenho no interior da Sociedade civil e em ação construtiva com o Estado, superando todo sonho de neocristandade.

\section{g. Nova relação da Igreja com o mundo}

A Constituição Gaudium et spes confessou a íntima sintonia dos cristãos com os homens e mulheres de hoje nas alegrias e esperanças, nas tristezas e angústias ${ }^{8}$. Modificou a atitude básica em face dos problemas fundamentais do mundo moderno. Reconheceu a autonomia das realidades temporais, terrestres, renunciando aos últimos resquícios da cristandade.

\section{h. Dimensão de serviço}

A Constituição dogmática Lumen gentium assumiu como determinante para o exercício do ministério ordenado a atitude básica de Jesus servidor.

${ }^{7}$ J. DELUMEAU, Guetter l'aurore. Un Christianisme pour demain, Paris: Grasset, 2003, pp. $197 \mathrm{ss}$.

${ }^{8}$ Constituição Pastoral Gaudium et spes, n. 1. 
O tríplice múnus dos ministros ordenados é entendido como serviço à comunidade. E a Igreja, enquanto todo, se definiu, como tal, em relação ao mundo. E cada cristão se entendeu no espírito do lava-pés de Jesus a serviço do irmão.

\section{i. Concepção ampla de santidade}

Até então, se não na realidade, ao menos no imaginário do católico comum, a santidade estava reservada primeiramente para os religiosos e eventualmente para o clero diocesano. E só em casos excepcionais para leigos. O Concílio modificou tal concepção, tratando, primeiro, da vocação universal à santidade e só depois dos modos específicos de vivê-la. Tal perspectiva propiciou o surgimento de diversas espiritualidades leigas na Igreja, tendo algumas influenciado até o clero e religiosos/as.

\section{j. Maria vista numa tríplice relação: Cristo, Igreja, fiel}

A figura de Maria, como aparecia em certas expressões da piedade católica, produzia nos evangélicos a suspeita de ela diminuir o papel redentor de Cristo. O Concílio afastou-se de tal visão, ao transformar o Decreto sobre Maria em capítulo da Lumen gentium e ao referir-se a Maria como a fiel discípula de Jesus, vista no projeto histórico-salvífico de Deus. Atribuiu-lhe a missão de conduzir o fiel à Igreja e a Cristo, sem nenhum detrimento da pessoa de Jesus Cristo.

\section{k. Clima de amplo diálogo: interno e externo à Igreja}

Os textos do Concílio mantêm a relevância da estabilidade do escrito. Entretanto, um evento daquela natureza ultrapassou-lhes de longe o significado, criando em torno de si um clima, um imaginário. Nasceu a consciência de autonomia e do pluralismo da modernidade, que exige diálogo tanto no interior da Igreja quanto em relação às instâncias e pessoas fora dela. Fracassara definitivamente o sistema de Cristandade e da pura ortodoxia em que se impunham as verdades pela força da autoridade.

\section{Valorização do "carisma" em relação à instituição}

No mesmo clima e imaginário criado pelo Concílio, inverteu-se a sensibilidade no interior da Igreja católica. Até o pontificado de Pio XII, pesavam fortemente as estruturas e impunha-se a mentalidade jurídico-canônica. $\mathrm{O}$ ar carismático de leveza, liberdade e criatividade, insuflado pelo pontificado de João XXIII e pelas novidades do Concílio, invadiu o conjunto da Igreja.

\section{m. Mudança da teologia básica}

O Concílio significou novo paradigma teológico em comparação com a teologia comum pós-tridentina e pré-moderna. $\mathrm{Cl}$. Geffré formulou como 
se deu a passagem da teologia dogmatista para a hermenêutica ${ }^{9}$. Consistiu na mudança da concepção de verdade que antes vinha toda do lado do objeto. Primeiro se estabelecia a tradição, depois o sujeito envolvido por ela. No horizonte longínquo estava o mundo rural com a matriz da natureza. O sujeito inseria-se numa tradição sem tomar distância dela e sem olhá-la como objeto de análise. Anterior ao cogito de Descartes.

A teologia dogmatista se preocupava por conhecer a essência e a substância das coisas, a verdade imutável. Elaboravam-se abstratamente os conceitos, suas mútuas relações, suas implicações. Desses conceitos, deduziam-se muitas conseqüências teóricas por meio, sobretudo, da lógica formal e da argumentação em silogismos. Recorria-se à autoridade dos antigos para estabelecer as verdades. Foi a leitura teológica usada amplamente na neoescolástica, especialmente pós-tridentina, redigida precipuamente em latim.

O Vaticano II assumiu a perspectiva hermenêutica que concentra a atenção em interpretar as verdades dogmáticas para a mentalidade de cada época, de cada cultura. O sujeito se aproxima da realidade já com uma pré-compreensão subjetiva e histórica. Interpreta, portanto, a realidade e esta, por sua vez, modifica-lhe a pré-compreensão.

De maneira simples e direta, a natureza do conhecer humano é interpretar, e isso acontece também respeito à revelação e às verdades dogmáticas. Todo conhecimento conjuga o elemento objetivo da verdade, a realidade que se conhece e o aspecto subjetivo de quem conhece. Na construção da verdade faz-se necessário o diálogo para atingi-la mais plenamente, e não a imposição feita pela autoridade ${ }^{10}$.

\section{Opções básicas de Medellín}

Paulo VI pretendia com a Conferência Geral dos Bispos da América Latina em Medellín aplicar o Concílio neste continente. No entanto, ela se configurou recepção criativa que o interpretou com perspicaz originalidade. Modificou-lhe a pergunta fundamental. Dirigiu a toda a Igreja católica do Continente a interpelação: que SERVIÇO se pode prestar ao povo pobre num continente de opressão e libertação? Que significa comprometer-se num contexto de América Latina?

${ }^{9}$ Cl. GEFFRÉ, Croire et interpréter. Le tournant herméneutique de la théologie, Paris: Cerf, 2001.

${ }_{10}$ A. Torres Queiruga dedica boa parte de sua teologia para desmontar essa teologia dogmatista, pré-moderna. Veja p. ex.: Fin del cristianismo premoderno: retos hacia un nuevo horizonte, Santander: Sal Terrae, 2000. 


\section{a. Mudança do contexto}

Já não se viviam os anos de otimismo do tempo conciliar. Implantara-se no Continente um capitalismo transnacional, apoiado pela ideologia do desenvolvimentismo. Para desmascará-la, economistas da CEPAL elaboraram a teoria da dependência. Em vez de desenvolvimento, propugnava-se libertação no interior dos países e em face dos países centrais. No programa entravam as reformas de base.

O mundo político incendiou-se com o surgimento de movimentos populares e estudantis, com a conscientização e organização dos sindicatos urbanos e rurais, e sobretudo com movimentos revolucionários, uns clandestinos, outros a céu aberto. A revolução cubana exercia atração. Personagens simbólicas como Fidel, Che Guevara, Camilo Torres e outras povoavam o horizonte utópico, especialmente dos jovens.

Em contrapartida, a repressão militar e policial organizava-se, financiada de dentro e de fora pelos interesses burgueses, chegando a construir regimes de exceção, ditatoriais. Apoiavam-se na Ideologia da Segurança Nacional. Assistiu-se a sucessão de golpes militares a partir de 1964 no Brasil, depois em 1966 na Argentina, em 1968 no Peru. Esse clima de tensão envolveu Medellín.

No âmbito cultural, a pedagogia de Paulo Freire, a instalação de centros de cultura popular, Movimentos de Educação de Base alimentavam propostas revolucionárias. E o clima mundial, que explodiu na França em Maio de 1968, favorecia na América Latina a esperança revolucionária até mesmo pela via armada.

A Igreja, plantada nesse clima de euforia, transformação, mudança rápida e expectativa revolucionária, foi atravessada por período de experiências audazes em diversos campos de sua vida.

Recordemos alguns dados e fatos. Reforçou-se a abertura social de João XXIII e do Concílio Vaticano II, defendendo-se a mística de uma Igreja dos pobres. Paulo VI, com a encíclica Populorum progressio, aprofundou o tema da pobreza e da Igreja no $3^{\circ}$ Mundo. Entrou em cena uma plêiade de bispos de extrema abertura social, de valor intelectual e evangélico, cuja expressão maior era D. Hélder Câmara. A Igreja do Brasil firmou a maravilhosa experiência de colegialidade. A Ação católica, especialmente sob a forma de JUC, JEC e JOC, mostrou pujança apostólica e crítico-social em relação à política do Estado e à própria Igreja. As comunidades eclesiais de base começaram a surgir no Nordeste do Brasil e depois em muitos outros lugares. A vida religiosa inseriu-se em meios populares no espírito de abertura do Vaticano II. Cristãos leigos e alguns sacerdotes e religiosos, em nome da fé, participaram da política revolucionária, despertando a fúria de setores conservadores eclesiásticos e da sociedade burguesa. 
Essa vigorosa agitação intra e extraeclesial fecundava a teologia e se alimentava dela. Na Europa, elaboraram-se as teologias do mundo, das realidades terrestres, política, da esperança e da revolução. E, no coração de Medellín, gestou-se a teologia da libertação, cuja forma programática apareceu no livro de G. Gutiérrez ${ }^{11}$, alguns anos depois.

Nesse contexto complexo e tumultuado, que respostas Medellín ofereceu para a Igreja da América Latina?

\section{b. Principais respostas de Medellín a esse contexto}

Os bispos e teólogos interpretaram, em termos de significado e de práxis, à luz da categoria teológica dos sinais dos tempos, a realidade social e eclesial do Continente, especialmente o conflito entre opressão e libertação.

Contra esse horizonte, realçaram na evangelização a dimensão temporal no tocante às estruturas sócio-políticas e econômicas, deixando uma tradição de mero ensinamento de verdades e prescrições morais.

Para tanto, lançaram mão da metodologia do VER-JULGAR-AGIR, a qual beberam em duas fontes: na tradição da JEC, JUC e JOC, e na Constituição Pastoral Gaudium et spes.

O novo enfoque social da evangelização desautorizou e rompeu a aliança entre Igreja (Cristianismo) e as forças conservadoras do status quo, isto é, da oligarquia latino-americana que há séculos vinha dominando a Igreja e apoiando-se nela.

No centro e coração das decisões de Medellín fulgiu a opção pelos pobres sem adjetivos nos diversos campos: social, intraeclesiástico, educacional, pastoral, vida religiosa, ministerial, etc. Tal opção visava à libertação dos pobres. A categoria de libertação fez entrada no cenário eclesial e teológico. Passou por uma transformação de sentido. Vindo das ciências políticas sofreu ampliação histórico-antropológica e terminou incluindo a dimensão teológica.

Pesou nesse momento a influência da pedagogia conscientizadora e libertadora de Paulo Freire, que ensaiava no Nordeste brasileiro as primeiras experiências da alfabetização de adultos que fosse simultaneamente politização crítica respeito à sociedade capitalista.

No interno da Igreja, bispos, sacerdotes, religiosos assumiram maior pobreza e singeleza de vida, despojando-se de antigos aparatos de ostentação, riqueza e bem-estar para assumir teor de vida próximo ao povo simples, abandonando a segurança de instituições poderosas. O contacto com

${ }^{11}$ G. GUTIÉRREZ, Teología de la liberación, Lima: CEP, 1971. 
as camadas populares resultou na valorização de sua religiosidade. Deixou-se de encará-la sob o prisma da ignorância, da pura alienação, para descobrir nela germes de sabedoria e libertação.

Incrementaram-se as comunidades eclesiais de base, articulando intimamente fé e vida, compromisso religioso e social. Nessa onda renovadora eclesial, a presença da Bíblia se fez fundamental. Deixou de ser um livro hermético, conhecido unicamente pelo clero, para ir às mãos do povo. Criaram-se círculos bíblicos que seguiram a genial metodologia de C. Mesters ${ }^{12}$.

A pregação, a teologia e a prática da Igreja focalizaram a justiça social. Superou-se concepção intimista do pecado, trabalhando a realidade do pecado social ${ }^{13}$. Condenou-se a violência institucional do próprio sistema e não unicamente a das guerrilhas e luta armada.

Resumindo, a Igreja, como todo, assumiu postura profética nos discursos, práticas, instituição. Predominou o aspecto sócio-estrutural e concentrouse na libertação dos pobres.

\section{Opções básicas de Puebla}

Dez anos depois de Medellín, bispos da América Latina reuniram-se em Puebla. Pretenderam responder à pergunta fundamental: Como re-situar Medellín na nova conjuntura política e eclesial da América Latina e da Igreja?

\section{a. Contexto da pergunta}

Eram outros tempos políticos e, sobretudo, eclesiais. A repressão atingia sintomas paroxísticos. Os regimes militares levavam o arbítrio, as torturas, os assassinatos a graus insuportáveis. O capitalismo transnacional impunha impunemente regras à economia, submetendo os países periféricos à dura espoliação. Os Estados nacionais perdiam autonomia. O crescimento do neoliberalismo desfazia as conquistas sociais. No campo cultural, a censura ideológica fechava os horizontes críticos. A situação política repressora se justificava pela ilusão do milagre econômico. O Brasil cresceu

${ }^{12}$ C. MESTERS, Mirar en el espejo de la vida, Buenos Aires: Centro Bíblico Ecuménico, 1993; ID., Círculos Bíblicos, Petrópolis: Vozes, 1973; ID., Por trás das palavras, Petrópolis: Vozes, 41980; ID., Flor sem defesa, Petrópolis: Vozes, 1983; ID., "O Projeto "PalavraVida" e a leitura fiel da Bíblia de acordo com a Tradição e o Magistério da Igreja", REB 49 (1989) 661-673; T.M.P. CAVALCANTI, O método de leitura popular da Bíblia na América Latina. A contribuição de Carlos Mesters. Tese de doutoramento, Departamento de Teologia, PUC-Rio de Janeiro, 1991.

${ }_{13}$ FREI BETTO, "Dimensão social do pecado", Grande Sinal 29 (1975) 491-502; J. ALDUNATE, "El pecado social: teoría y alcances", Teología y Vida 24 (1983) 99-110; CL. BOFF, "Pecado social", in ID., Comunidade eclesial - comunidade política: ensaios de eclesiologia política, Petrópolis: Vozes, 1978, pp. 157-184. 
durante os Governos militares na base de $10 \%$ ao ano, aproveitando vácuo existente. $\mathrm{O}$ sistema alardeava-se desse crescimento. Mas já no final do regime militar esgotava-se tal "maravilha", preparando o processo de democratização.

Para a Conferência de Puebla, as mudanças eclesiais pesaram mais. Logo depois de Medellín, já apareciam os primeiros sinais de reação às iniciativas inovadoras pós-conciliares e ao surto libertador da Igreja latino-americana por parte de Roma e de setores conservadores eclesiásticos do nosso Continente. Por bem da verdade, eles nunca assimilaram nem o Vaticano II nem Medellín. Adquiriam então força depois de alguns anos de recesso tímido diante das ondas libertárias sociais e eclesiais. Como estas arrefeceram, os conservadores puderam levantar a cabeça, escondida sob a avalanche libertadora.

$\mathrm{Na}$ base das reações conservadoras escondia-se certa decepção com os rumos que a Igreja tomara no embalo do Concílio. Diante da encíclica Humanae vitae de Paulo VI (1968), surgiram reações de oposição até mesmo por parte de episcopados. A ampla laicização de dezenas de milhares de sacerdotes assustava. O final melancólico do Pontificado de Paulo VI preparava clima de reação. Num momento de sofrimento, ele confessou ter a sensação de que "por alguma fresta entrou a fumaça de Satanás no Templo de Deus"14. Ele esperava que depois do Concílio viria um dia de sol para a história da Igreja. Veio, ao invés, um dia de nuvens, de tempestade, de escuridão, de procura, de incerteza. Pregamos o ecumenismo e nos afastamos sempre mais uns dos outros. Cavamos abismos em vez de fechá-los ${ }^{15}$.

Na América Latina, o CELAM que organizou o Encontro de Puebla assumira linha cada vez mais conservadora. Denunciava que na Igreja latinoamericana se fizera falsa interpretação de Medellín, ao radicalizarem-se a opção pelos pobres, o compromisso social, a base da Igreja - leia-se comunidade eclesial de base - numa verdadeira "Igreja popular". Além disso, acusava a vida religiosa, propugnada pela CLAR e consubstanciada na inserção popular de religiosos/as, de "magistério paralelo" em atrito com bispos locais. Estigmatizara a teologia da libertação de marxismo. Verberava as Conferências episcopais regionais por excessiva autonomia - entenda-se sobretudo a Conferência Nacional dos Bispos do Brasil. Esse clima de suspeita infeccionou amplos setores eclesiásticos latino-americanos e instâncias romanas.

Entre a convocação de Puebla por Paulo VI e sua realização, houve a morte de dois pontífices e a eleição de João Paulo II. Bem no início do pontifica-

${ }^{14}$ L'Osservatore Romano de 29/06/1972.

${ }^{15}$ A. MELLONI, "O que foi o Vaticano II? Breve guia para os juízos sobre o Concílio", Concilium 312 (2005/4) 36/460. 
do, desconhecendo naturalmente a realidade da Igreja da América Latina, o Papa fez longo discurso inaugural da Conferência, refletindo a tendência eclesial de desconfiança em face da Igreja da libertação, que se remetia às opções de Medellín.

Era então, pensavam os conservadores, o momento de reconduzir as Igrejas do Continente ao leito seguro do controle institucional por parte de Roma no campo interno da vida eclesiástica e na atuação na sociedade. Na organização de Puebla predominou tal preocupação de modo que os teólogos da libertação foram sistematicamente excluídos de alguma assessoria. O longo documento de Puebla desconheceu a teologia da libertação, como se ela não existisse. E ela tinha sido a primeira teologia original do Continente. É realmente espantoso para um olhar de historiador constatar essa ausência total até das palavras "teologia da libertação"!

Evidentemente a tendência conservadora não encontrava unanimidade entre os bispos. Mesmo tendo eliminado da aula episcopal os teólogos da libertação, houve bispos que se assessoraram com eles fora do âmbito estrito da Conferência. Alguns deles eram pessoas de renomada credibilidade pela vida, cultura, inteligência. Esse jogo produziu o texto oficial e as opções de Puebla. Se, de um lado, ele se alinhou ao clima geral de suspeita, no entanto fez concessões à Igreja da libertação por causa do corte evangélico de suas propostas, da coragem profética de alguns bispos e até mesmo por causa de afirmações do Papa. Esse, depois da abertura, entrou em contacto com o sofrimento do povo mexicano e produziu afirmações corajosas que o documento teve de incorporar, dando-lhe abertura social tanto na parte do diagnóstico quanto na das propostas pastorais.

\section{b. Respostas de Puebla}

A nitidez e a contundência das opções de Medellín receberam no documento de Puebla matizes. Ele enfraqueceu as opções centrais pelos pobres e pela libertação, adjetivando-as e complexificando-as. Sem negá-las, Puebla suavizou-lhes os contornos. Assim a opção pelos pobres recebeu série de adjetivos. Falou-se de opção preferencial, de amor preferencial e solicitude (382), de preferência pela evangelização e serviços dos pobres (707), de compromisso preferencial (769), não exclusivo (1145). E depois apuseram ao substantivo "opção" muitos outros adjetivos: evangélica, não ideológica, etc.. Essa adjetivação e expressões adversativas terminaram enfraquecendo a radicalidade de Medellín.

A entrada da opção pelos jovens teve o lado positivo de chamar atenção para esse grave problema da Igreja e negativo de diminuir o impacto da opção pelos pobres. "Divide et impera", diziam os romanos.

Puebla deslocou o termo libertação para evangelização libertadora. O substantivo virou adjetivo: enfraquecimento semântico. A realidade e a religi- 
osidade popular são vistas já preferentemente sob o aspecto cultural. Falou-se do substrato radical católico como fruto da evangelização constituinte e de uma religiosidade popular simples a ser resguardada diante da secularização. O movimento libertador era incluído na onda secularizante. O tema da evangelização da cultura começou a crescer em importância.

O binômio "comunhão e participação" tornou-se eixo estruturante da Igreja. Atribuiu-se relevância à Igreja particular com certa paroquialização das CEBs. Defendeu-se a dignidade da pessoa diante das violações presentes nos regimes militares. Propugnou-se ação junto aos construtores da sociedade com atenção à intelligentsia da sociedade e não só aos pobres.

Resumindo: deslocou-se o acento para o aspecto cultural e multiplicaramse as opções, enfraquecendo destarte a opção pela libertação dos pobres, tão cortante em Medellín.

\section{Opções básicas de Santo Domingo}

A pergunta central em Santo Domingo soou diferente: em pleno processo de contenção eclesiástica e de desconfiança respeito à Igreja da libertação, como reconduzir a Igreja a essas novas orientações romanas?

\section{a. Contexto sociocultural e eclesial}

A situação sociopolítica e econômica nos idos de 1992 reforçara o neoliberalismo com as conseqüências sabidas, gestando novo tipo de pobreza: desemprego, exclusão, proximidade da morte. Outros efeitos nefastos se fizeram sentir: a centralidade absoluta do mercado, o desfazimento dos "entulhos sociais" da Segurança Social, o rompimento das fronteiras comerciais e o enrijecimento das políticas econômicas neoliberais.

Culturalmente, cresceu a importância do conhecimento em todos os campos. A exclusão cultural de países e segmentos sociais radicalizou-se no interior da sociedade do conhecimento. Quem não tem acesso ao saber, segrega-se do mundo real e perde-se na noite da pobreza quase total.

E na Igreja, somaram-se dois movimentos antitéticos, mas que até agora convivem. O reforço neoconservador das instituições eclesiásticas e a onda carismática fizeram refluir o compromisso social e libertador. Entretanto, outros movimentos sociais, também de força libertadora, surgiram nos diversos países e bateram à porta da Igreja: movimentos feminista, ecológico, pacifista, anti-racista, inter-religioso.

\section{b. Respostas de Santo Domingo}

A experiência de Santo Domingo foi, em parte, traumatizante. A Igreja da América Latina teve pouca liberdade de expressão em Assembléia organi- 
zada desde os poderes centrais da Igreja. Apesar de recuos, houve também pontos ganhos e novos.

Firmaram-se algumas linhas tendenciais. A problemática social, voltada para a luta contra a injustiça em vista da transformação da sociedade, deslocou-se para a evangelização da cultura moderna, chamada de adventícia, recorrendo à telemática. A cultura afro-ameríndia e a religiosidade popular ofereceram plataforma para a inculturação da fé, respeitando certas restrições no campo litúrgico.

A evangelização se pensou em ação contrária à cultura moderna, restaurando ou criando nova cultura. Reinou desconfiança em relação à modernidade e aos processos transformadores da realidade social. Entretanto, sem polemizar diretamente com a modernidade, optou-se por criar uma cultura de valores estáveis, cristãos, informando a cultura latinoamericana com eles, em vez de acentuar o aspecto da mudança social. $\mathrm{O}$ projeto inicial de criar única cultura cristã terminou compondo-se com a aceitação do fato da pluralidade de culturas, procurando impregná-las, porém, de valores absolutos cristãos.

A opção pelos pobres, segundo a posição predominante em Santo Domingo, tem provocado certo radicalismo e exclusivismo no interior da Igreja. Preferiu-se insistir na dimensão universal da evangelização a protagonizar os pobres. Não se esqueceu a opção pelos pobres, mas ela foi matizada,

No consoante a aspectos da vida interna da Igreja, acentuaram-se mais a conformidade que a diversidade, o poder central que as instâncias locais, a obediência que a liberdade, a tradição que as experiências novas e criativas, o comum que o original, o aspecto espiritual da santidade que o compromisso. Esse conjunto de preferências configurou cenário conservador e espiritualista.

No entanto, deu-se, ao menos na letra e nos desejos, significativo passo, ao afirmar o protagonismo dos leigos. Abriu-se aí porta para avanços maiores que, em geral, estão à espera de iniciativas dos próprios leigos.

A Conferência de Santo Domingo se reuniu no clima da memória do descobrimento das Américas e da Primeira evangelização. Olhando para esta, o Papa e, na sua seqüência, as Igrejas do Continente estenderam o gesto de pedido de perdão aos povos indígenas e aos negros trazidos como escravos. Significou ato de humildade em relação ao passado, mas, ao mesmo tempo, atitude de crítica e contínua revisão pastoral a fim de não repetir faltas da gravidade do passado.

Santo Domingo embarcou na proposta da Nova Evangelização, que vinha sendo agitada desde o discurso de João Paulo II ao CELAM, em Porto Príncipe (Haiti), a 9 de março de 1983, no qual ele afirmou dever o V 
Centenário da evangelização ser um compromisso "não de reevangelização, mas sim de uma evangelização nova. Nova em seu ardor, em seus métodos, em sua expressão"16. A mesma expressão repetiu em outros momentos de suas viagens apostólicas à República Dominicana ${ }^{17}$, ao Uruguai ${ }^{18}$.

A expressão "nova evangelização" carregava certa ambigüidade. Para uns, significou a diminuição da dimensão libertadora, o reforço do aspecto espiritualista, midiático e da exterioridade de personagens da Igreja, máxime o Papa, Teresa de Calcutá, Chiara Lubich, etc. Outros descobriram que Medellín já falara de nova evangelização para incluir a temática libertadora e ampliaram-na para uma solidariedade latino-americana e mundial.

Santo Domingo manteve viva a categoria "sinais dos tempos", recordando uma das idéias-chave de João XXIII, Vaticano II e Medellín. Em termos de América Latina, ela soava como interpretação privilegiada do processo libertador de dentro da situação de opressão.

Resumindo, atravessaram Santo Domingo duas opções de fundo em tensão. Uma ia na direção de apoiar, incentivar as comunidades eclesiais de base (CEBs) com a conseqüente opção pelos pobres sem mais. A outra preferia insistir nos movimentos apostólicos de leigos de cunho internacional, tais como: renovação carismática, comunhão e libertação, focolare, movimento neocatecumenal. Assim se processava uma matização da opção pelos pobres já em curso desde antes de Puebla. Esta foi hegemônica, enquanto a outra apenas residual.

\section{Conclusão}

Esse rápido percurso pelo Concílio Vaticano II e pelas três Conferências do Episcopado latino-americano permite-nos resgatar de todas as opções feitas aquelas que julgamos imprescindíveis e inegociáveis para levá-las à Assembléia de Aparecida. Dois verbos soam-nos como palavra de ordem: resgatar e resistir. Resgatar as opções fundamentais da Igreja do Continente e resistir às forças que as vêm minando desde décadas.

\section{Avançar para temas e decisões novas}

Uma vez garantidas as opções anteriores, cabe-nos avançar pontos que venham responder a novas situações e que se tornaram hoje prementes. À

\footnotetext{
${ }^{16}$ AAS 75 (1983) 778.

${ }^{17}$ L'Osservatore Romano, ed. port., xv n. 776, 14.10.1984, pp. 1, 2, 16.

${ }^{18}$ L'Osservatore Romano, ed. port., xix, 15.5.1988.
} 
guisa de esboço, indicamos alguns elementos relevantes para a Igreja na atual conjuntura social e eclesial.

\section{Rever o ministério ordenado à luz das opções do Vaticano II e Medellín}

Tal revisão implica a superação do autoritarismo e do centralismo pastoral. Infelizmente se têm observado na geração jovem clerical traços autoritários. Isto tem a ver com a formação em seminários, que voltaram a moldarse a modo de "instituição total"19. Esse clero tem acentuado "os sinais distintivos de sua condição - festas, vestes, poderes -, ausência de inquietação com relação ao destino da sociedade (e da Igreja), pouco amor (nenhum?) aos estudos, nenhuma paixão pelo ecumenismo, pela justiça social. Presbíteros mais preocupados com seu caráter e poder sagrados do que com uma presença significativa no mundo, com o diálogo com a sociedade, com serviço competente ao homem de hoje ${ }^{\prime 20}$. Impõe-se encontrar a via da simplicidade e da proximidade do clero com as pessoas.

Indo mais longe e mais alto, até mesmo secundando desejos de João Paulo II na Encíclica Ut unum sint, impõe-se redimensionar o magistério oficial e a hierarquia eclesiástica no espírito de serviço e singeleza ${ }^{21}$.

Na esteira das inovações do Vaticano II, a Igreja revitalizou a instituição do diaconato permanente, aberto também ao homem casado. Temos já tempo suficiente para submeter o exercício dessa ordem à revisão na tríplice alternativa da continuidade ou da reformulação do atual exercício ou mesmo de abolição desse ministério em nosso contexto pastoral. Nessa direção se fazem estudos a partir das experiências em curso $^{22}$.

A impossibilidade de celebrar a eucaristia semanal na maioria das comunidades católicas ${ }^{23}$ obriga gravemente a Igreja a pensar em soluções mais eficientes, contundentes e a curto prazo. Não resolve reduzir a questão do ministério ordenado ao problema de promoção vocacional, embora ela tenha relevância. Põe-se em horizonte mais amplo.

${ }^{19}$ L.R. BENEDETTI, “O 'Novo Clero': Arcaico ou moderno?”, REB 59 (1999) p. 89.

${ }^{20}$ IBIDEM.

${ }^{21}$ J.R. QUINN, Reforma do papado: indispensável para a unidade cristã, Aparecida: Santuário, 2002.

${ }_{22}$ M. DWULATKA, Diaconato Permanente: Ministério Evangelizador na Comunhão e na Missão da Igreja, Dissertação de Mestrado, Departamento de Teologia da Faculdade Jesuíta de Filosofia e Teologia, Belo Horizonte, 2006.

${ }^{23}$ Dados do Centro de Estatísticas da Conferência Nacional dos Bispos do Brasil apontam uma média de $70 \%$ de comunidades que aos domingos têm celebração sem eucaristia por simples falta de ministro ordenado: R. VALLE / M. PITTA, Resultados estatísticos do levantamento nacional das comunidades eclesiais católicas, Rio de Janeiro: Centro de Estatística Religiosa e Investigações Sociais, 1993. 
Estão em pauta três questões relacionadas com essa situação: reincorporar ao exercício do ministério presbíteros que foram reduzidos ao estado laical ou estão sem cidadania eclesiástica, a ordenação de homens casados de valor indiscutível e o ministério ordenado das mulheres. No momento, esta última questão se encontra fortemente bloqueada pelo teor contundente do documento de João Paulo $\mathrm{II}^{24}$. Permanece ainda aberta a questão da diaconisa. Isso poderia ser um primeiro golpe que quebrasse a armadura eclesiástica.

\section{Pensar seriamente uma "renovação litúrgica" popular}

O Vaticano II continuou e aprofundou a reforma da liturgia romana clássica com profícuo fruto espiritual e pastoral. As celebrações litúrgicas adquiriram pujante vitalidade. Semelhante empreendimento necessita ser levado a cabo na liturgia popular em diálogo com a cultura popular religiosa afro-ameríndia. Implica aprofundar a importância teológica e social da religiosidade popular, especialmente em nível de comunidades de base.

Já é tempo de levar a sério a reserva católica da América Latina, invertendo o processo de influência. Em vez de deixar-se plasmar por orientações vindas de matriz européia ou norteamericana, influenciar essas instâncias com o vigor, a criatividade e a originalidade do catolicismo mestiço, moreno.

\section{Animação "carismática" das estruturas internas da Igreja}

O fenômeno carismático está aí com gigantesco vigor. Como não perceber nele um sinal do Espírito? Como toda ação de Deus na história, ele padece de ambigüidade e carece de discernimento. A onda carismática possui enorme potencial transformador das instituições, se ela realizar o princípio jesuano de que "o sábado é feito para o homem e não o homem para o sábado". Em outras palavras, cabe-lhe maravilhosa tarefa de humanizar, de espiritualizar, no sentido pleno do termo, a rigidez de muitas formas institucionais e jurídicas da Igreja. Isso inclui revigorar a dimensão de diaconia, de pobreza, de simplicidade no ser, vestir, viver dos representantes da Instituição eclesiástica.

Os movimentos carismáticos adotam, por vezes, posições antitéticas. Alguns se apresentam fortemente centralizados na pessoa do líder. Estes não ajudam a libertar a Igreja de formas centralizadoras e autoritárias. Outros, porém, cultivam transparente liberdade entre os membros. Eles têm condições de pensar e ensaiar um modelo "democrático" e participativo de

${ }_{24}^{24}$ JOÃO PAULO II, "Ordinatio Sacerdotalis": Carta apostólica aos Bispos da Igreja Católica sobre a ordenação sacerdotal reservada somente aos homens, Petrópolis: Vozes, 1994. 
Igreja. E se se articulam com as CEBs, antecipam já uma Igreja, rede de comunidades no interior das paróquias e dioceses. E então a Igreja se torna para o fiel uma comunidade de liberdade, diálogo, acolhida, igualdade. E nesse mesmo espírito, facilita-se assumir o princípio de subsidiariedade no governo da Igreja.

\section{Enfrentar o fenômeno religioso e das espiritualidades}

A onda carismática tem outra face: o surto do fenômeno religioso com exuberante efervescência de novas espiritualidades. Existem para todos os gostos. Que fazer? O futuro da Igreja depende da maneira como ela discernirá essa mistura religiosa e de espiritualidades, valorizando as que lhe trazem renovação e evangelizando as que a desviam das opções do Vaticano II e Medellín. A evangelização à luz da pneumatologia paulina da liberdade purifica as experiências religiosas dos restolhos míticos, mágicos, fundamentalistas, meramente emocionais e desenquadra-as de ritos espirituais rígidos.

\section{Estabelecer com os novos movimentos relação de comunhão responsável e livre}

Os novos movimentos eclesiais de espiritualidade e apostolado pululam. Sobre eles fazem-se análises matizadas. João Paulo $\mathrm{II}^{25}$ e o card. Ratzinger, em algumas de suas manifestações ${ }^{26}$, manifestaram certo entusiasmo. A recente tomada de posição crítica diante do movimento do neocatecumenato manifesta, talvez, já certa inflexão do otimismo anterior ${ }^{27}$. Outros autores criticam-nos fortemente ${ }^{28}$.

Como tarefa, temos condições de submetê-los a um processo de discernimento, captando-lhes o lado criativo e animador, e apontando-lhes os riscos e limites. Enquanto novidade, leveza, criatividade, valorização da

${ }^{25}$ G. URQUHART, A armada do papa: os segredos e o poder das novas seitas da Igreja Católica, Rio de Janeiro: Record, 2002: o autor cita inúmeras vezes afirmações e demonstrações de apreço de João Paulo II aos novos movimentos eclesiais. João Paulo II, na celebração de Pentecostes de 1998, aplica a passagem de Joel citada por Pedro (At 2,17) a estes movimentos que reuniam na praça de São Pedro uns 500.000 adeptos: "Hoje a Igreja se rejubila com a renovada confirmação das palavras do profeta Joel que acabamos de ouvir: 'Eu derramarei meu Espírito sobre vossa carne' (At 2,17). Vocês, presentes aqui, são a prova tangível deste 'derramamento' do Espírito".

${ }^{26}$ J. RATZINGER / V. MESSORI, A fé em crise. O cardeal Ratzinger se interroga, São Paulo: EPU, 1985, pp. 27s; "Conferenza del Card. Ratzinger: Movimenti ecclesiali e loro collocazione teologica”, Il Regno 43 (1998/13), n. 818, p. 400.

${ }^{27}$ Discurso do Papa Bento XVI aos Membros do Caminho Neocatecumenal, Sala Paulo VI, Quinta-feira, 12 de janeiro de 2006, no qual ele remete a práxis litúrgica do neocatecumenato às normas relativas à celebração eucarística, emanadas, em seu nome, pela Congregação para o Culto Divino e a Disciplina dos Sacramentos.

${ }^{28}$ G. URQUHART, A armada do papa, op. cit. 
presença do Espírito Santo, liberdade, têm muito que contribuir num momento de refluxo autoritário. Mas, à medida que incorporam aspectos conservadores e autoritários com detrimento para as comunidades locais reforçam o lado negativo da conjuntura eclesial atual.

Alguns deles começaram com convicções ecumênicas, com experiências transconfessionais, privilegiando Pentecostes em contraponto ao institucional, valorizando as experiências espirituais e comunitárias. No entanto, pouco a pouco se tornaram fundamentalistas e agressivos, numa defesa virulenta da própria identidade ${ }^{29}$. As Igrejas da América Latina têm diante de si a tarefa de potencializar esses movimentos eclesiais na direção de articulá-los:

a) com a vida pastoral da Igreja local;

b) com as comunidades eclesiais de base em mútua fecundação;

c) com compromissos sociais na linha da opção pelos pobres.

\section{Enfrentar a nova sociedade globalizada do conhecimento}

Cada dia avançam mais as ciências e a alta tecnologia, especialmente no campo das ciências da vida e da informação, trazendo graves problemas éticos. O conhecimento torna-se a matéria prima sobremaneira importante no mundo da produção, do gerenciamento das empresas. Fora do conhecimento, perdem-se as concorrências.

A Igreja necessita de leigos/as e professores/as de ética e de teologia moral, preparados para tal diálogo. Um laicato destemido e competente, apoiado pelo magistério, o pouparia de declarações oficiais infelizes e sem conhecimento suficiente em temas difíceis, complexos e ainda penumbrosos.

A sociedade do conhecimento está a gerar novo tipo de pobre e excluído. Desafia a Igreja descobrir-lhe a face concreta e real, como fez em Puebla (nn. 31-39). Isso significa avançar além da opção pelos pobres de Medellín e Puebla, desadjetivando-a de epítetos ideológicos e enfraquecedores, para recuperar-lhe a força evangélica. Numa palavra, estamos diante da tarefa de retomar com amplidão a prática da libertação no contexto neoliberal.

\section{Purificar a linguagem teológica}

O Concílio Vaticano II e a teologia da libertação produziram profunda transformação da linguagem teológica pré-moderna, escolástica, essencialista, fixista. Arrancaram-lhe entulhos tradicionais, ao usar no discurso e na pregação linguagem acessível aos fiéis de hoje.

${ }^{29}$ J. DELUMEAU, Guetter l'aurore, op. cit., pp. 236ss. 
Em termos simples, a linguagem teológica necessita responder a:
a) experiência existencial das pessoas situadas na pós-modernidade de modo que lhes seja significativa;
b) exigência de compromisso social com os pobres;
c) avanços contínuos das ciências;
d) demandas éticas;
e) surto religioso;
f) valorização do simbolismo, da metáfora, do gênero narrativo.

\section{Enfrentar a evangelização da cultura}

Torna-se impensável uma evangelização que não leve em consideração a cultura. $\mathrm{O}$ fracasso do socialismo real deveu-se, além das falhas econômicas, ao fato de não ter criado culturalmente o homem novo desejado. Descuidou a cultura.

A presença da Igreja na sociedade futura depende de como ela se situar no campo cultural. O caminho passa, não por uma adaptação cultural aos valores burgueses capitalistas, mas pela construção de uma cultura a partir dos pobres. O socialismo criou imaginário da libertação, mas fracassou pela ausência de valores fundamentais. A Igreja tem condições de unir ao imaginário libertador social traços evangélicos, dando-lhe consistência e profundidade. A evangelização da atual cultura moderna e pós-moderna requer que se construa no interior da Igreja e fora dele, por meio da pastoral, de discursos, de práticas, de instâncias e de símbolos, um imaginário que expresse a opção pela libertação dos pobres. Só assim se consegue transformar a realidade.

Em outros termos, isso significa a criação de novo paradigma cultural, como verdadeira alternativa ao pensar único dominante, o qual leve em consideração as maiores conquistas do momento atual: pensar ecológico, cosmologia moderna, o gênero, as etnias, a paz, a ética do cuidado e da compaixão ${ }^{30}$.

\section{Encontrar canais jurídicos}

O espírito e o carisma do Vaticano II e de Medellín desaparecerão, se, de certa maneira, não se institucionalizarem. As suas opções principais não podem depender unicamente da boa vontade das pessoas - bispos, páro-

${ }^{30}$ L. BOFF, Ecologia: Grito da terra, Grito dos pobres, São Paulo, Atica, 1995; ID., Ecologia, mundialização, espiritualidade. A emergência de um novo paradigma, São Paulo, Atica, 1993. 
cos ou líderes -, mas devem assumir caráter injuntivo e ser regulamentadas de maneira concreta, do contrário se tornam pios desejos. À guisa de exemplos: que a relação entre as conferências episcopais e os bispos diocesanos adquira caráter vinculante em determinados assuntos; que as escolhas de párocos, bispos, se façam de maneira obrigatória com maior participação dos fiéis interessados; que os Conselhos diocesanos até os das comunidades não assumam meramente foro consultivo e decorativo, mas tenham poder decisório, etc.

\section{Desenvolver eficiente pastoral dos migrantes}

As migrações se tornam fenômeno crescente no mundo inteiro e no interior dos países a desafiar a pastoral da Igreja. Já são centenas de milhões os que se movem dentro dos países e para fora deles em migrações crescentes. Por que deixam a própria terra? E por que buscam outra terra e qual ela é? Jogam fatores de expulsão e de atração. Do lado objetivo, encontramos a pobreza, a falta de futuro onde se está, a crescente segregação econômica, racial e religiosa, os conflitos internos regionais. Do lado subjetivo, faíscam sonhos de riqueza, dos EUA de dinheiro fácil e abundante, de amealhar rapidamente recursos para resolver definitivamente a questão da habitação e de outras exigências básicas. Pobreza e sonho, falta de futuro e ilusão de futuro radioso. É a carência do ser humano que Frei Betto chamou de "fome de pão e de beleza"31.

A pastoral do futuro enfrentará desde a defesa dos direitos fundamentais do migrante, sobretudo os dos indocumentados, até uma migração do clero e religiosos juntos. Enquanto caminhamos lentamente ou dormimos, as denominações evangélicas pentecostais e neopentecostais ocupam rapidamente esses espaços. Nem sempre para o bem das pessoas. Não nos movem razões proselitistas, mas unicamente as de lealdade evangélica e amor àqueles que caem presa fácil de distorções religiosas.

\section{Repensar a pastoral familiar em moldes plurais}

Levando em consideração as novas formas de família que escapam do modelo tradicional - pai, mãe, filhos - exige-se da pastoral do futuro abertura maior em relação àquelas famílias que não respondem à figura tradicional defendida pela Igreja.

Requerem-se melhores conhecimentos psicológicos e sociológicos para enfrentar essa nova situação. Não bastam a teologia e a pastoral tradicionais que comandaram até hoje a ação da Igreja. Os discursos do magistério

${ }^{31}$ FREI BETTO, Fome de pão e de beleza, São Paulo: Siciliano, [19—]. 
distam muito desses novos desafios. O papel de um laicato entendido na política familiar se torna imprescindível para tal pastoral. O clero celibatário dificilmente consegue captar muitos dos problemas que atravessam a família.

\section{Investir pesadamente numa pastoral midiática}

A ciência e a tecnologia da comunicação passam por revolução jamais vista. Anunciam-se saltos tecnológicos imensos que estão a revolucionar a relação entre as pessoas e a criar nova geração de usuários.

Os desafios pastorais consistem, entre outros aspectos, na presença significativa da Igreja nesse universo tecnológico e cultural e na articulação de tais meios com as exigências comunitárias da vida cristã, com a disciplina do arcanum e com as características próprias da fé cristã.

A mídia constitui-se muito mais que simples instrumento de comunicação. Configura a atual cultura. Uma linguagem teológica que não levasse em conta esse dado cultural passaria à margem dos ouvintes e leitores. Como se trata de cultura, o empenho tem de ser muito maior em profundidade, percebendo as modificações de comportamento, de horizonte simbólico das pessoas. Somente aí dentro se evangeliza.

\section{Conclusão}

Este texto visa, neste momento de preparação para Aparecida, a provocar uma reflexão, discernimento e confecção de subsídios em vista da V Assembléia do CELAM. Embora algo amplo, foi redigido de forma sucinta e sumária à espera de ulteriores contribuições.

\section{Bibliografia de J. B. Libanio sobre o tema}

1. "A Igreja que sonhamos construir", REB 65 (2005), n. 260, pp. 787-816.

2. Olhando para o futuro. Perspectivas teológicas e pastorais do Cristianismo na América Latina, São Paulo: Loyola, 2003.

3. A Religião no início do milênio, São Paulo: Loyola, 2002.

4. Concílio Vaticano II. Em busca de uma primeira compreensão, São Paulo: Loyola, 2005.

5. Qual o futuro do Cristianismo?, São Paulo: Paulus, 2006.

6. "Concílio Vaticano II: Tarefas pendentes para a Igreja no Brasil hoje". Seminário comemorativo dos 40 anos do Concílio Vaticano II, organi- 
zado pelo Instituto Nacional de Pastoral da Conferência Nacional dos Bispos do Brasil em Itaici de 08 a 10 de fevereiro de 2006, em vias de publicação.

7. "Concílio Vaticano II: Os anos que se seguiram", in A. LORSCHEIDER (org.), Vaticano II. 40 anos depois, São Paulo: Paulus, 2005, pp. 71-88.

João Batista Libanio, SJ, doutor em Teologia pela Pontifícia Universidade Gregoriana Roma (1968); é professor de Teologia na Faculdade Jesuíta de Filosofia e Teologia, em Belo Horizonte; fundador e membro da SOTER (Sociedade de Teologia e Ciências da Religião); Vigário Paroquial de Nossa Senhora de Lourdes (Vespasiano); autor de obras, entre as quais, de publicação recente: Teologia da Revelação a partir da modernidade, São Paulo: Loyola, $5^{\mathrm{a}}$ ed., 2005; Eu Creio - Nós Cremos: Tratado da Fé, São Paulo: Loyola, $2^{a}$ ed., 2004; As lógicas da cidade, o impacto sobre a fé e sob o impacto da fé, São Paulo: Loyola, 2001; A arte de formar-se, São Paulo: Loyola, 4ª ed., 2004; Introdução à vida intelectual, São Paulo: Loyola, $3^{\mathrm{a}}$ ed., 2006; A religião no início do milênio, São Paulo: Loyola, 2002; Olhando para o futuro: perspectivas teológicas e pastorais do Cristianismo na América Latina, São Paulo: Loyola, 2003; Gustavo Gutiérrez, São Paulo: Loyola, 2004; Jovens em tempo de pós-modernidade: considerações socioculturais e pastorais, São Paulo: Loyola, 2004; Como saborear a celebração eucarística? São Paulo: Paulus, 2a. ed., 2005; Qual o caminho entre o crer e amar? São Paulo: Paulus, $2^{\text {a }}$ ed., 2005; Concílio Vaticano II. Em busca de uma primeira compreensão. São Paulo: Loyola, 2005; Qual o futuro do Cristianismo? São Paulo, Paulus: 2006.

Endereço: Av. Dr. Cristiano Guimarães, 2127

31720-300 Belo Horizonte - MG

e-mail: jblibanio@cesjesuit.br 